\title{
The effect of piston bowl temperature on diesel exhaust emissions
}

N Ladommatos ${ }^{1 *}, \mathrm{Z} \mathrm{Xiao}^{2}$, and $\mathrm{H} \mathrm{Zhao}^{3}$

${ }^{1}$ Department of Mechanical Engineering, University College London, London, UK

${ }^{2}$ University of Warwick, Coventry, UK

${ }^{3}$ Department of Mechanical Engineering, Brunel University, Uxbridge, UK

The manuscript was received on 8 April 2004 and was accepted after revision for publication on 1 September 2004.

DOI: 10.1243/095440705X6550

\begin{abstract}
In modern, high-speed, direct injection diesel engines for passenger vehicles, there is extensive impingement of the fuel sprays on to the piston bowl walls. Recent trends towards smaller engine sizes, equipped with high-pressure common-rail fuel injection systems, have tended to increase the spray/piston wall interaction. This paper describes tests carried out in a high-speed direct injection automotive diesel engine, during which the temperature of the piston was increased in a controlled manner between 189 and $227^{\circ} \mathrm{C}$ while being continuously monitored. The aim of the work was to quantify the effects of piston temperature on pollutant exhaust emissions. The results show a significant reduction in unburned hydrocarbon emission, a significant increase in smoke emission, and no significant change in the emission of oxides of nitrogen. The increase in smoke emission cannot be ascribed to changes in the engine volumetric efficiency or air-fuel ratio. The paper demonstrates that fuel spray deposition on the piston surface was in the form of a thin film that did not experience bulk boiling. A number of suggestions are put forward to help explain the observed changes in exhaust emissions with increasing piston temperature.
\end{abstract}

Keywords: piston bowl, diesel exhaust, emissions, direct injection diesel engine, piston temperature, particulate, smoke

\section{INTRODUCTION}

In diesel engines the piston is cooled, principally, through heat transfer to the engine block coolant, the engine oil, and to the incoming air charge. The prime purpose of cooling the piston is to ensure that it maintains sufficient strength to withstand the stresses imposed on it by gas pressure and inertial forces. Any effect that the piston surface temperature might have on the combustion and pollutant emission generation has not been a prime consideration in diesel engine design. Nevertheless, in modern highspeed direct injection diesel engines for passenger vehicles, there is extensive impingement of the fuel sprays on to the piston bowl walls. Recent trends towards smaller engine sizes, equipped with highpressure common-rail fuel injection systems, have

\footnotetext{
* Corresponding author: Department of Mechanical Engineering, University College London, Torrington Place, London, WC1E 7JE, UK.email: n_ladommatos@meng.ucl.ac.uk
}

tended to increase the spray/piston wall interaction. Several investigators have shown that raising the wall temperature can affect, considerably, both the fluid mechanics close to the piston surface as well as the spray evaporation and droplet size distribution [1-6]. Experimental results by Rao et al. $[\mathbf{7}, \mathbf{8}]$ show that in a high-speed direct injection diesel engine, equipped with high-pressure unit injectors, 75 per cent of the injected fuel reached the piston bowl walls at high engine loads. This resulted in fuel-rich local mixtures and higher unburned hydrocarbon emissions in the exhaust. Some further evidence that piston temperature can affect exhaust emissions is provided by Miyamoto et al. [9] who conducted transient tests on a high-speed direct injection diesel engine. Their results show that a higher piston surface temperature reduced the concentration of unburned hydrocarbons in the exhaust and also affected the concentration of oxides of nitrogen and smoke emission.

This paper describes tests carried out in a highspeed direct injection automotive diesel engine, during 
which the temperature of the piston was altered in a controlled manner and continuously monitored. The aim of the work was to quantify the effects of piston temperature on pollutant exhaust emissions.

\section{EXPERIMENTAL SYSTEM}

\subsection{Control of the piston temperature}

Details of the four-cylinder automotive-type diesel engine used for the tests are shown in Table 1. The engine was coupled to a hydraulic dynamometer which allowed independent control of the engine load and speed.

The main aim of the project was to isolate the effect of piston surface temperature on exhaust pollutant emissions. Therefore, a method was required that would allow the piston surface temperature to be altered without altering the temperature of the other combustion chamber surfaces. In order to achieve this requirement, the engine cooling system was split into two identical, but independently controlled, circuits, as shown in Fig. 1. One circuit was for the engine block and the other for the engine head. The independent engine head circuit permitted the head coolant temperature to be kept always constant throughout the test programme at $90^{\circ} \mathrm{C}$. This ensured that combustion chamber surfaces associated with the engine head were kept at a constant temperature. The other independent cooling circuit for the engine block was used to alter the piston surface temperature. By altering the block coolant temperature, between 45 and $105^{\circ} \mathrm{C}$, it was possible to control the piston temperature over a wide range. The piston temperature was actually measured while the engine was running, as explained in a subsequent section of this paper. Unfortunately, this method of controlling the piston temperature also altered the temperature of the cylinder walls exposed by the piston. However, the cylinder wall surface

Table 1 Details of the automotive diesel engine used for the tests

\begin{tabular}{|c|c|}
\hline \multicolumn{2}{|c|}{$\begin{array}{l}\text { Engine type: } \\
\text { Four-cylinder, in-line, overhead valve, direct injection, } \\
\quad \text { turbocharged } \\
\text { Injection system: } \\
\text { Rotary fuel pump with electronic injection timing control }\end{array}$} \\
\hline Bore $(\mathrm{mm})$ & 93.67 \\
\hline Stroke $(\mathrm{mm})$ & 90.54 \\
\hline Displacement (litres) & 2.5 \\
\hline Maximum power output (kW) & 52 at $4000 \mathrm{r} / \mathrm{min}$ \\
\hline Maximum torque $(\mathrm{N} \mathrm{m})$ & 145 \\
\hline Compression ratio & 19:1 \\
\hline
\end{tabular}

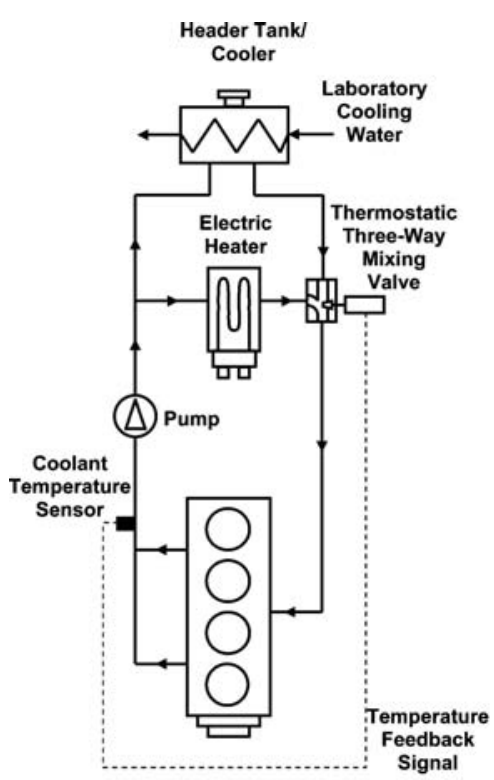

Engine Block Circuit

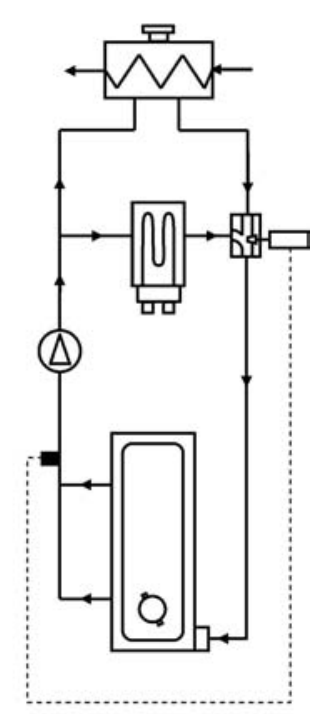

Engine Head Circuit
Fig. 1 Cooling circuits for engine block and engine head

temperature had much less influence on the combustion process than the surface temperatures of the piston and the head. This is particularly true at lower engine loads, when the amount of cylinder wall area exposed during combustion is relatively small. Alternative ways to control the piston temperature were considered, but were not employed. These included an oil gallery in the piston, under-piston oil jets, and heating the piston electrically. The oiljet option was rejected after preliminary analysis indicated that a substantial rise in lubricating oil temperature would have been required in order to raise the piston temperature significantly. There was concern that such high temperatures would have degraded the oil lubricating properties. The use of a piston oil gallery was rejected because the modification of the standard piston to include a gallery would have required major redesign work and remanufacture, which were beyond the resources available for this project. Finally, the option of electrically heating the piston was rejected because substantial power requirements were predicted, making this option impractical and potentially unsafe.

In order to split the two cooling circuits shown in Fig. 1, a special engine head gasket was used, which had the water-transfer holes un-punched. The temperature of each cooling circuit was controlled by a thermostatic three-way mixing valve (see Fig. 1). The mixing valve for the head circuit maintained the coolant temperature at the exit to the head always constant at $90^{\circ} \mathrm{C}$. The mixing valve for the engine 
block maintained the coolant temperature at the exit from the block constant at any desired set value between 45 and $105^{\circ} \mathrm{C}$.

The two electric heaters shown in Fig. 1 were used to pre-heat the coolant in the engine head and block, prior to starting the engine. This reduced the engine cumulative running time and, thereby, the strain on the piston temperature measuring system.

\subsection{Measurement of the piston temperature}

As mentioned previously, the piston temperature was measured while the engine was running. In this way, it was possible to relate directly the engine exhaust emission levels to the piston temperature.

Over the years, a variety of methods has been developed for the measurement of temperatures in the pistons of running engines. Most of these methods use temperature sensors that are usually installed through drillings, which reach just below the piston surface. Commonly used temperature sensors are thermocouples, thermistors, and resistance thermometers. Transferring the sensor signals from such sensors to a stationary logging system outside the engine is a technically demanding task which has stimulated, over the years, the development of a variety of techniques.

A technique that is used frequently involves the routeing of signal wires down the piston connecting rod to the moving big-end bearing cap. A hinged linkage system is used to support the wires between the moving big-end cup and a stationary point on the engine crankcase [9-12]. Cyclic bending of the wires at various articulations can lead to wire fatigue and breakage, and, thereby, a limited system lifetime.

The contact technique is a rather simple method for transferring the temperature sensor signals out of the engine. The signal wires are brought to a convenient connector, e.g. at the bottom of the piston skirt. When the piston is at bottom dead centre (BDC), this connector makes intermittent contact with a mating stationary connector on the engine crankcase. The brief contact period is sufficient to transfer the signals to a logging system outside the engine. Such systems are simple to apply but can have a limited lifetime of a few hours, often due to failure of the mating connectors. They have, nevertheless, been applied successfully at speeds up to $12000 \mathrm{r} / \mathrm{min}$ [13].

Several non-contact techniques have also been developed, which have no physical connection between the piston and the logging system. A frequently used one involves telemetry, often using infrared (IR) wavelengths. An IR transmitter on the piston skirt transmits the signals to an IR receiver on a stationary point on the engine crankcase $[\mathbf{1 4}, \mathbf{1 5}]$. Often the temperature sensor signals are conditioned and multiplexed, before being fed to a voltage-tofrequency converter and the IR transmitter [16], all within the piston. Power for the piston hardware can be provided by an on-board battery or generated by a small power generator that utilizes the motion of the piston [17]. Care is needed with IR telemetry systems to avoid obscuration of the transmitter and receiver IR diodes by engine oil. The electronic hardware must also be small and sufficiently robust to withstand the high inertial forces generated by the reciprocating motion of the piston. Another noncontact technique involves inductive transfer of the signals from a moving coil on the piston skirt to a stationary coil on the crankcase. The strength of the inductive coupling between the two coils at piston bottom dead centre can be related to the piston temperature [18]. An advantage of this technique is the simplicity of the temperature sensing system carried by the piston, comprising only a thermistor and a resonator coil. However, one thermistor/resonator coil pair is needed for each temperature measuring point on the piston. Two other non-contact techniques rely on piston surface thermography. The first thermographic technique involves the capture of a two-dimensional image of the energy emission from the piston surface in the IR band and the conversion of this image into a piston surface temperature map [19]. This technique requires optical access to either the whole piston surface or specific areas of interest on the piston surface. The second thermographic technique relies on the energy emitted from a very thin phosphorescent coating applied on to the piston surface. The coating fluoresces briefly when excited by an incident pulse of monochromatic light, and the rate of decay of the fluorescent energy can be related to the piston surface temperature [20]. As with the IR imaging method, this technique also requires optical access to the piston surface.

For the project described in this paper, a hinged linkage system was used to transfer the temperature signals from 15 thermocouples embedded in one of the four engine pistons. Previous experience with this system had shown it to be reliable and easy to calibrate. Fifteen type $\mathrm{K}$ thermocouples were installed in piston 4 (i.e. corresponding to the fourth cylinder of the engine). Figure 2 shows the location of these 15 thermocouples. Thermocouples numbered 1, 5, 6, 12, and 14 (see Fig. 2) were distributed around the piston bowl at the five spray impingement points. The tip of each thermocouple was installed approximately $1 \mathrm{~mm}$ below the exposed surfaces of the 


\section{Plan view of the bowl}

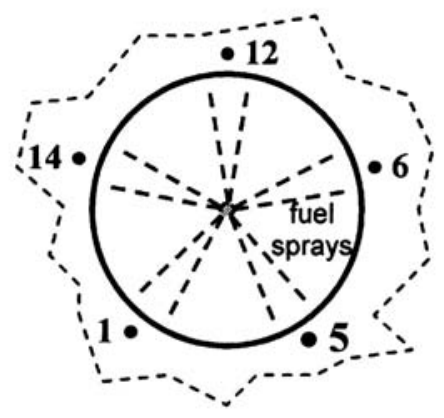

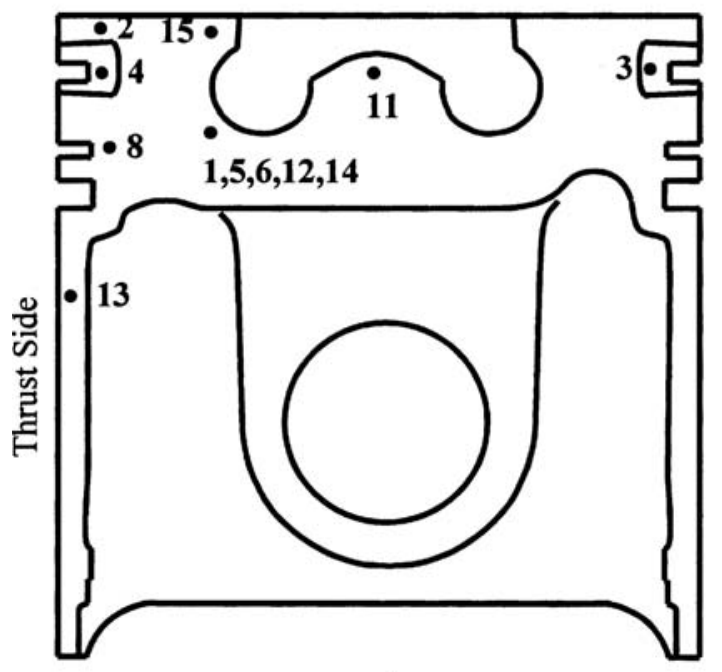

A

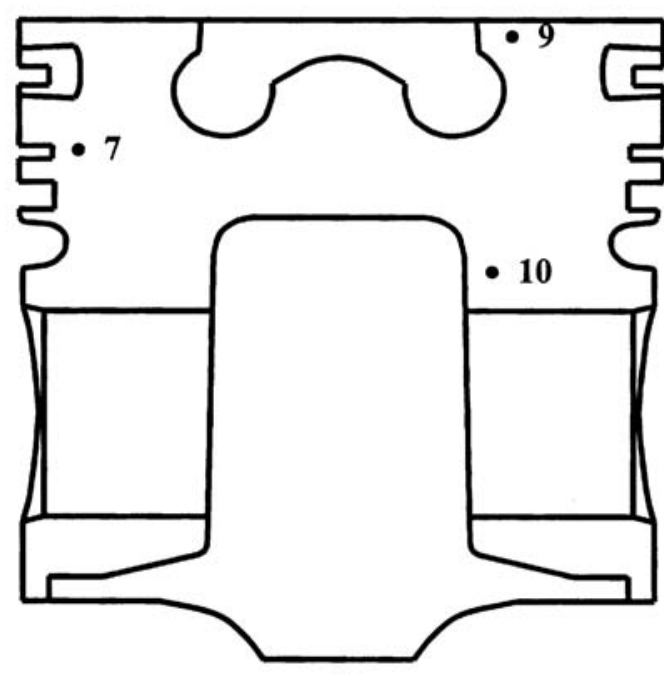

B

Fig. 2 Locations of thermocouples within the piston. View A is axial to the gudgeon pin, while view $B$ is transverse to the gudgeon pin. Thermocouples $1,5,6,12$, and 14 are distributed around the bowl at the five spray impingement locations ( denotes the thermocouple position)

piston. An interesting question is whether the temperature drop across $1 \mathrm{~mm}$ of piston material is significant. At engine part load, a typical piston surface heat flux, averaged over an engine cycle, is of order $0.3 \mathrm{MW} / \mathrm{m}^{2}[\mathbf{2 1}]$. With this flux, the temperature drop across $1 \mathrm{~mm}$ of the piston material has been estimated by the authors to be less than $2{ }^{\circ} \mathrm{C}$ and can therefore be neglected in comparison with the measured piston surface temperatures of more than $189^{\circ} \mathrm{C}$.

The wires of the 15 thermocouples embedded in the piston were not brought out of the moving piston, because they were prone to fatigue and failure when subjected to continuous cyclic bending. Instead, the wires for each thermocouple were connected to copper braided cables, which were more flexible and less prone to failure. The braided cables were then routed out of the piston to a stationary logging system. Before their connection to the braided cable, the thermocouples were split into two groups. The wires for seven of the thermocouples (first group) were routed to an isothermal junction pad attached to the inside surface of the piston skirt. Similarly, the wires of the remaining eight thermocouples (second group) were routed to a second isothermal junction pad positioned at another location on the inside surface of the piston skirt. At the junction pad, each thermocouple wire was connected to a flexible, braided copper cable. This resulted in two bundles of braided copper cables which were routed through the gudgeon pin on to the connecting rod and down the connecting rod to the big-end bearing cup. A hinged linkage system, with one end attached on to the moving big-end bearing and the other end attached on to the stationary engine crankcase, supported the bundle of braided copper cables. The cables emerged from the crankcase into a digital logging system that recorded automatically the signals from the 15 thermocouples and evaluated the temperature for each thermocouple. 
The evaluation of the thermocouple temperatures required knowledge of the temperatures of the two isothermal pads on the piston skirt, where the thermocouple wires were connected to the braided copper cables. The temperatures of the two isothermal pads were measured by two thermistors, one each for the two groups of thermocouples. There are three main reasons for splitting the 15 thermocouples into two groups and for using two thermistors, one for each group. Firstly, the size of each isothermal pad became smaller, and this ensured that all the connections carried by each pad were at the same temperature. Secondly, the smaller pad size and smaller associated wire bundle for each group were more easily accommodated in the limited space available on the piston. Thirdly, if one thermistor failed and the information from one thermocouple group was lost, the other group would still have been able to provide satisfactory information about the temperature distribution around the piston.

During the test programme the instrumented piston worked reliably, except for thermocouples 9 and 14, which failed calibration checks prior to the piston being installed on the engine. Readings from both these thermocouples were therefore disregarded throughout the test programme.

\subsection{Measurement of air and fuel flowrates and exhaust pollutant emissions}

The volumetric air flowrate supplied to the engine was continuously measured using a positive displacement air flowmeter. It was converted to the mass flowrate using the temperature and pressure at the exit to the meter, which were also monitored continuously. The volumetric fuel flowrate was measured with a calibrated burette and stopwatch and converted to the mass flowrate using the measured fuel density.

The molar concentration of the gaseous unburned hydrocarbon (HC) emissions in the engine exhaust was measured about $0.75 \mathrm{~m}$ downstream of the turbocharger turbine using a flame ionization analyser, which was frequently calibrated throughout the tests using propane $\left(\mathrm{C}_{3} \mathrm{H}_{8}\right)$ in nitrogen. The exhaust gas sample was supplied to the $\mathrm{HC}$ analyser through a heated pipe maintained at $200^{\circ} \mathrm{C}$. The molar concentration of oxides of nitrogen $\left(\mathrm{NO}_{x}\right)$ was also measured at this location using a chemiluminescence analyser. The sample was transferred to the analyser through a heated pipe maintained at $150{ }^{\circ} \mathrm{C}$ and the analyser was frequently calibrated during the tests. Smoke emission was measured with an automated
AVL system, which displayed values of smoke density in Bosch units, obtained from measurements of the reflectance of exhaust particulates deposited on filter paper tape.

\section{RESULTS AND DISCUSSION}

\subsection{Piston surface temperatures}

Figure 3 shows the temperature distribution around piston 4 , when the engine was running at an intermediate load of $80 \mathrm{~N} \mathrm{~m}$ at $2000 \mathrm{r} / \mathrm{min}$. It can be seen from the figure that the temperatures at the fuel spray impingement points (thermocouples 1, 5, 6, and 12) were among the highest recorded, reaching around $235^{\circ} \mathrm{C}$ at the block coolant temperature of $125^{\circ} \mathrm{C}$.

Figure 4 again shows the temperature distribution around piston 4 , but now at the higher engine load of $125 \mathrm{~N} \mathrm{~m}$ at $2000 \mathrm{r} / \mathrm{min}$. This running condition was close to engine full load. Comparing Figs 3 and 4 , it can be seen that the temperature distribution around the piston was very similar at the two engine loads. However, the increase in load caused the temperature at the fuel impingement points to climb from 235 to $265^{\circ} \mathrm{C}$. In general, the maximum temperature at the spray impingement points recorded in this project was $275^{\circ} \mathrm{C}$.

When the original piston 4 was removed from the engine, to be replaced by an identical instrumented piston, substantial and distinctive soot deposits were observed at each of the five fuel spray impingement points. The presence of these soot deposits confirmed that substantial fuel impingement was indeed taking place on the piston bowl walls. Much of the deposited fuel will, in one way or another, eventually evaporate off the piston surface and find its way back into the cylinder gas. The role of the piston temperature in how the fuel evaporates off the piston is an important one and will be discussed quantitatively in the following paragraphs.

Diesel fuel is a mixture of numerous hydrocarbon compounds. The most volatile components have boiling points around $170^{\circ} \mathrm{C}$ at atmospheric pressure, while the least volatile ones have much higher boiling points in excess of $300^{\circ} \mathrm{C}$ at atmospheric pressure. Consider, first, the thermodynamic behaviour of the most volatile components. Furthermore, in order to allow a quantitative discussion, let these most volatile components be represented by $n$-decane. $n$-Decane has a boiling point of $174{ }^{\circ} \mathrm{C}$ at atmospheric pressure and properties that are readily available in the literature [22]. 
Block coolant temperature: $\square 60 \mathrm{deg} C \quad \square 125 \mathrm{deg} C$

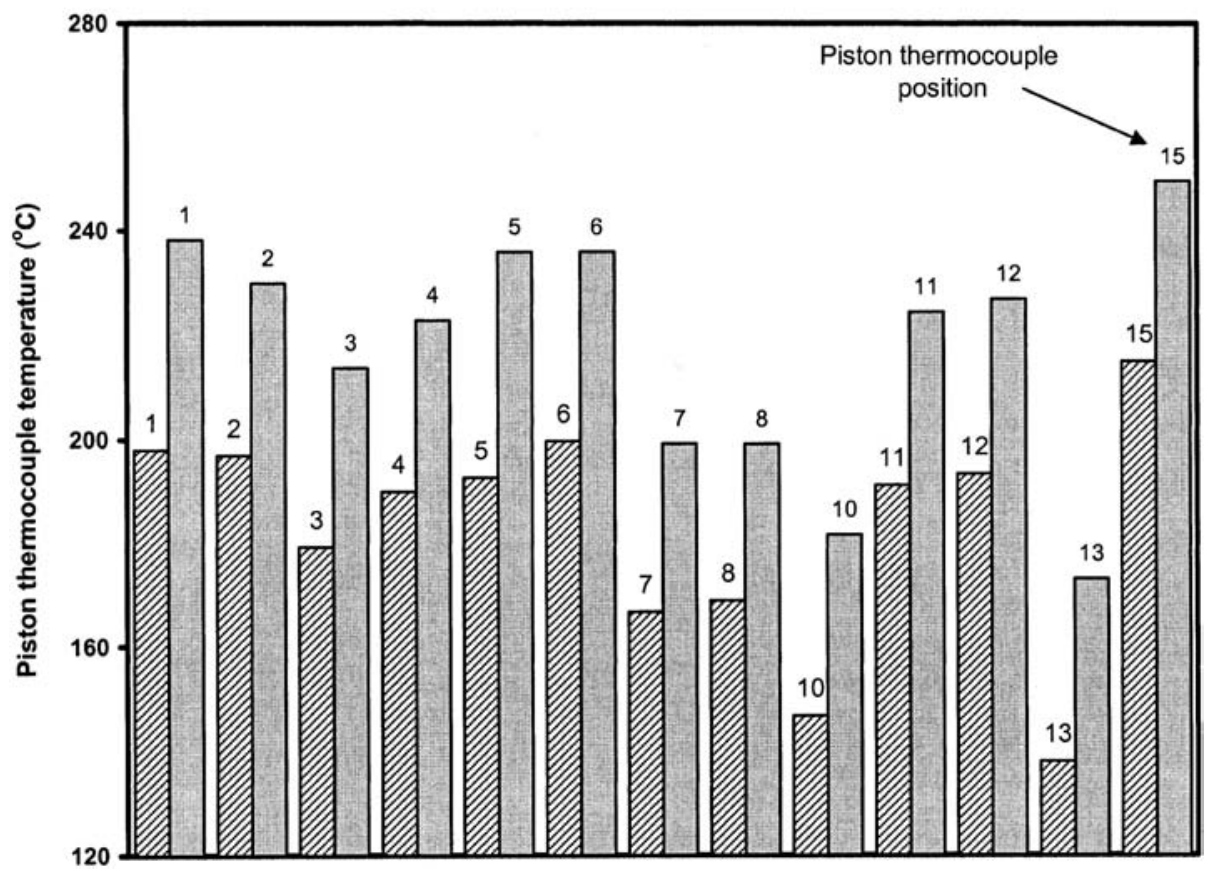

Fig. 3 Temperatures at various piston locations for two engine block coolant temperatures of 60 and $125^{\circ} \mathrm{C}$. Engine speed $2000 \mathrm{r} / \mathrm{min}$ and load $80 \mathrm{~N} \mathrm{~m}$, injection timing $1^{\circ} \mathrm{CA}$ BTDC, engine head temperature constant at $90^{\circ} \mathrm{C}$

Block coolant temperature: $\quad \square 65$ deg C $\square 125$ deg C

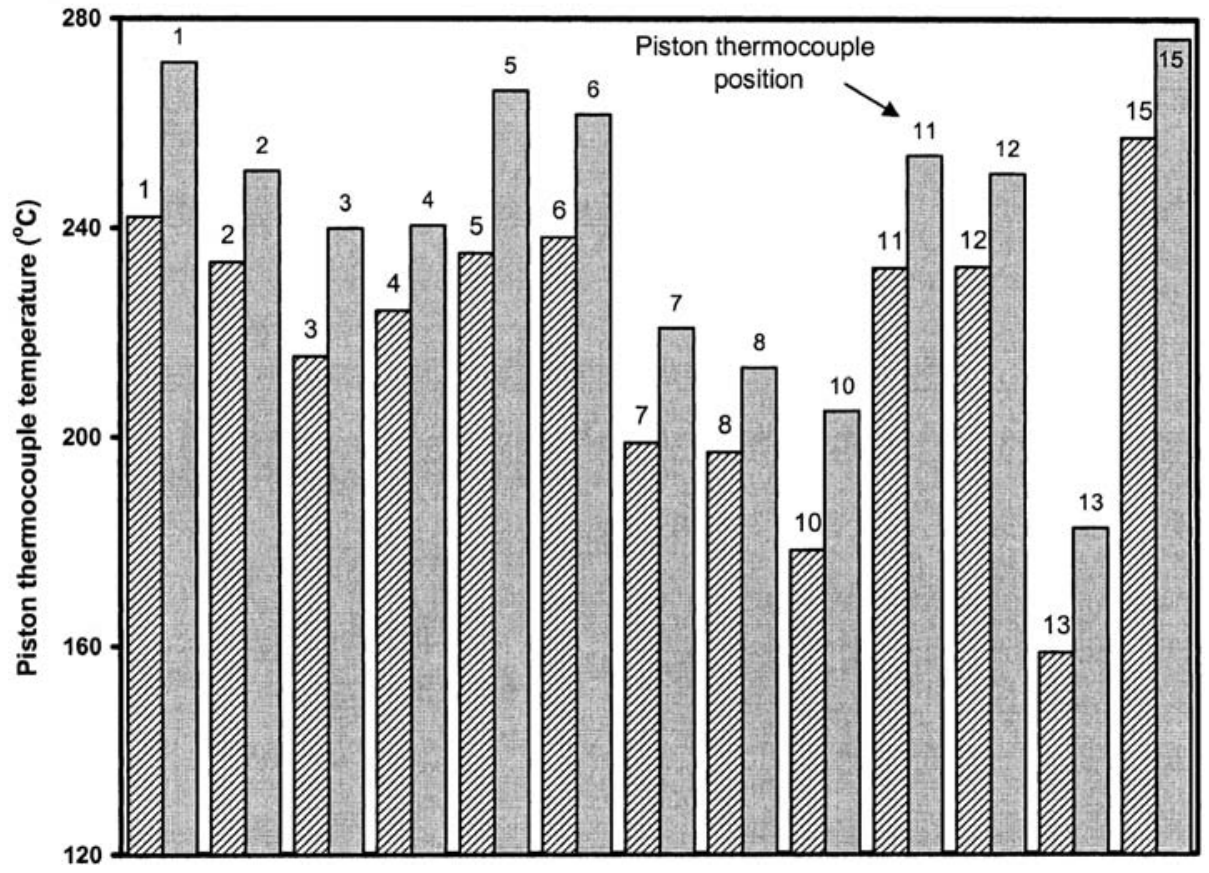

Fig. 4 Temperatures at various piston locations for two engine block coolant temperatures of 65 and $125^{\circ} \mathrm{C}$. Engine speed $2000 \mathrm{r} / \mathrm{min}$ and load $125 \mathrm{~N} \mathrm{~m}$, injection timing $1^{\circ} \mathrm{CA}$ BTDC, engine head temperature constant at $90^{\circ} \mathrm{C}$ 


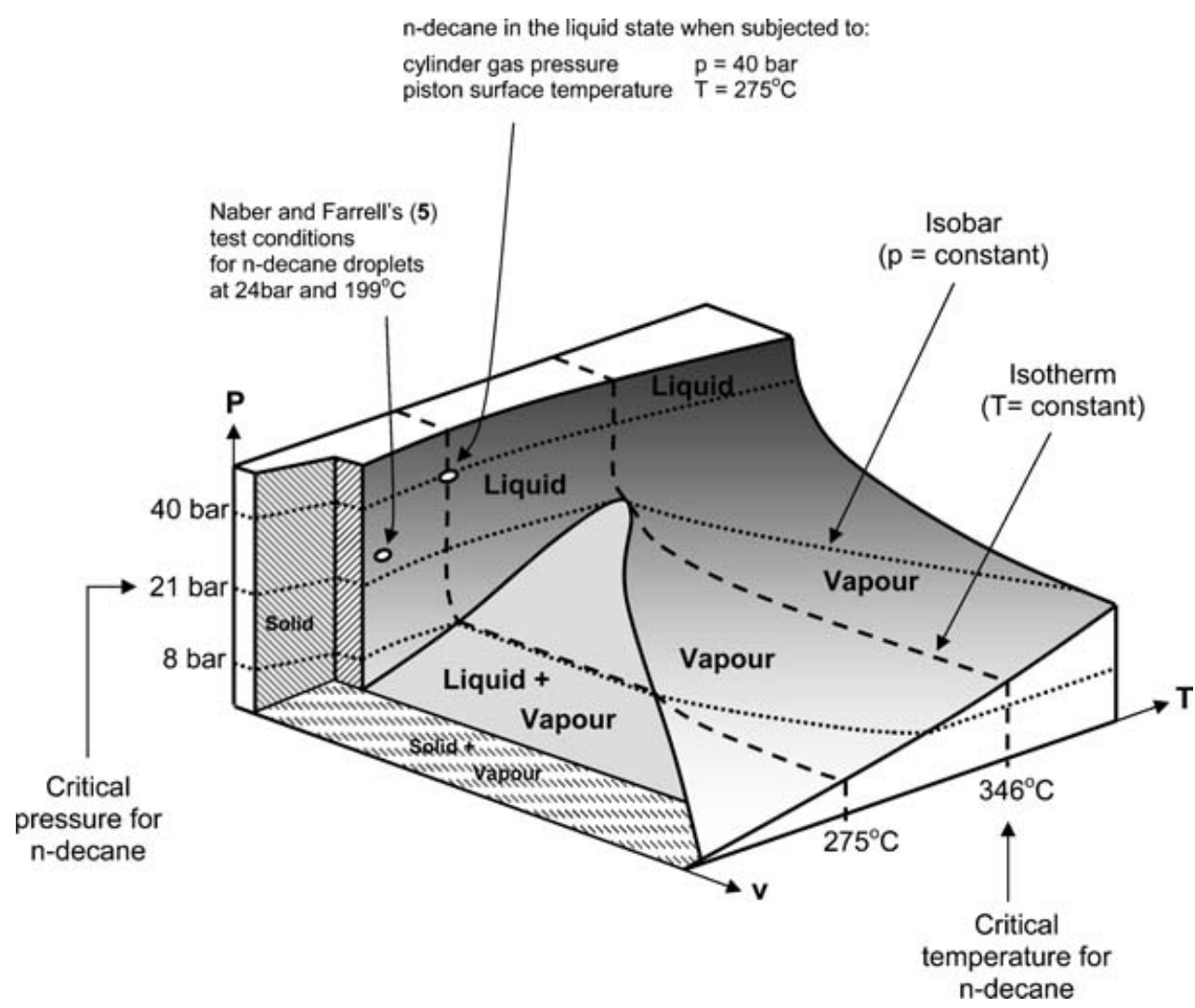

Fig. 5 Pressure-volume-temperature surface for the most volatile diesel fuel component (represented by $n$-decane) ( $p$ and $T$ axes are not drawn to scale)

Consider events in the engine cylinder before the start of combustion. As the piston was approaching top dead centre (TDC), the gas pressure was rising to 40 bar. The fuel deposited on to the piston bowl surface was, therefore, subjected to a pressure of around 40 bar. It will be shown later in this paper that the deposited fuel was spread on to the piston surface as a thin film. It is reasonable to assume that this film was sufficiently thin for its temperature to be close to the piston surface temperature of $275^{\circ} \mathrm{C}$. At $275^{\circ} \mathrm{C}$ the saturation pressure of $n$-decane is 8 bar [22]. This pressure is much smaller than the 40 bar acting on the film. It follows that the fuel film was far from boiling. In fact, the film is expected to have been in the 'compressed liquid' thermodynamic state [23], as shown in Fig. 5, on the pressurevolume-temperature surface. Figure 5 shows that the film could not boil at $275^{\circ} \mathrm{C}$ unless the cylinder gas pressure fell to 8 bar. In fact, the cylinder gas pressure did not fall to 8 bar until very late in the expansion stroke. Therefore, prior to the start of combustion, the fuel film was not boiling. Of course, the fuel film was vaporizing off the piston surface by means of forced evaporation. However, it was vaporizing only from its free surface, not through bulk boiling. Once combustion started, energy transfer by radiation and convection from the burning gases is expected to have increased this surface evaporation substantially.

Finally, the deposited fuel film could not have experienced the Leidenforst phenomenon, as this requires the boiling state to be reached first [24].

\subsection{Relation between coolant and piston temperatures}

The effect of the block coolant temperature on piston temperature is shown in Fig. 6 at $2000 \mathrm{r} / \mathrm{min}$ and $80 \mathrm{~N} \mathrm{~m}$. There is a roughly linear relationship between the piston and the coolant temperatures, irrespective of the piston thermocouple location. A similar near-linear relationship was also found at other engine running conditions (results not shown for the sake of brevity). Figure 6 shows that the coolant temperature had a major influence on the piston temperature. For example, the slope of the line for thermocouple 1 (spray impingement point) shows that for every $1{ }^{\circ} \mathrm{C}$ rise in the coolant temperature the piston temperature rose by $0.6{ }^{\circ} \mathrm{C}$.

The slopes of the lines in Fig. 6 are summarized in Fig. 7, which includes also the slopes for all the other engine conditions tested. Figure 7 shows that the piston temperature increased between 0.3 and 


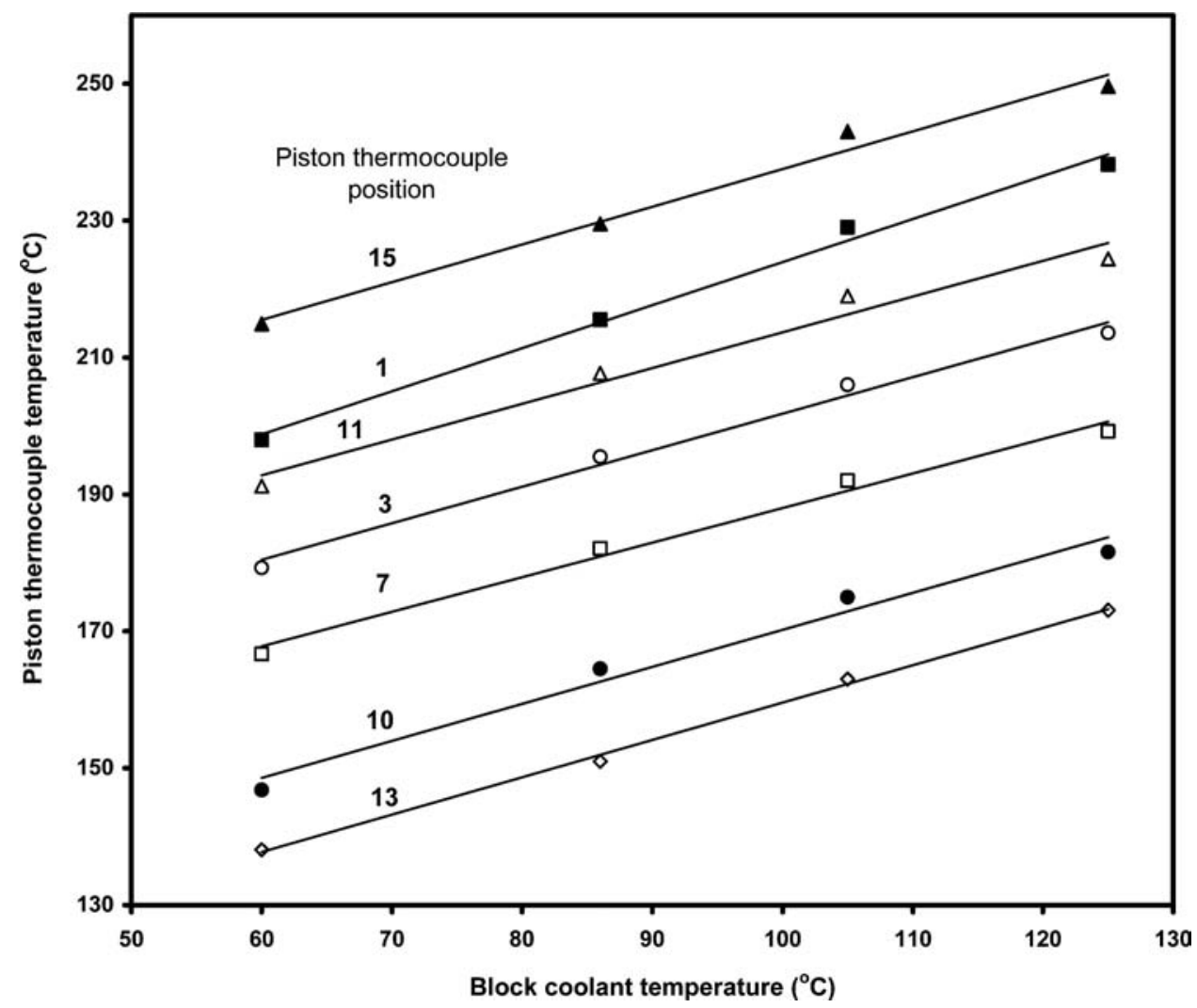

Fig. 6 The influence of engine block coolant temperature on the piston temperature. Engine speed $2000 \mathrm{r} / \mathrm{min}$ and load $80 \mathrm{~N} \mathrm{~m}$, injection timing $1^{\circ} \mathrm{CA}$ BTDC, engine head temperature constant at $90^{\circ} \mathrm{C}$

$0.6{ }^{\circ} \mathrm{C}$ for every $1{ }^{\circ} \mathrm{C}$ rise in block coolant temperature, depending on engine running conditions and thermocouple location. It is interesting to consider briefly why the piston temperature rise was within this range of 0.3 to $0.6^{\circ} \mathrm{C}$.

The combustion process caused a large energy input to the piston surface, which was subsequently transferred mainly to the engine coolant, the engine oil, and the air passing through the engine during the inlet/exhaust valve overlap period. It is the fact that this energy was transferred not just to the coolant but to several energy sinks that made the piston temperature rise less than unity. Had all the energy input to the piston been transferred only to the coolant, then a $1{ }^{\circ} \mathrm{C}$ rise in coolant temperature would have also caused a $1{ }^{\circ} \mathrm{C}$ rise in piston temperature. This is illustrated clearly by the analysis in the Appendix.

\subsection{Relation between injection timing and piston temperatures}

Figure 8 shows the influence of the injection timing on the piston temperatures at $2000 \mathrm{r} / \mathrm{min}$ and $80 \mathrm{~N} \mathrm{~m}$ load; both the engine head and block coolant temperatures were held constant at 90 and $95^{\circ} \mathrm{C}$ respectively. The relation between the timing and the piston temperatures was remarkably linear, albeit a weak one. Advancing the injection timing caused the piston temperatures to rise, reflecting a corresponding rise in the cylinder gas pressure and temperature. Figure 8 also shows the slopes of the lines. These slopes provide a measure of how sensitive the piston temperatures were to changes in injection timing. It can be seen from the figure that the increase in piston temperatures was between 0.9 and $1.9^{\circ} \mathrm{C}$ for each $1^{\circ}$ crank angle ( ${ }^{\circ} \mathrm{CA}$ ) of injection timing advance.

\subsection{Influence of the piston temperature on exhaust pollutant emissions}

\subsubsection{Unburned hydrocarbons}

Figure 9 shows the effect of piston temperature on $\mathrm{HC}$ exhaust emission. The figure shows that a rise in piston temperature had a substantial effect in reducing the exhaust $\mathrm{HC}$ emission. For example, with the injection timing set at $-1^{\circ} \mathrm{CA}$ (i.e. $1^{\circ} \mathrm{CA}$ BTDC), raising the piston temperature by $38^{\circ} \mathrm{C}$ (from 189 


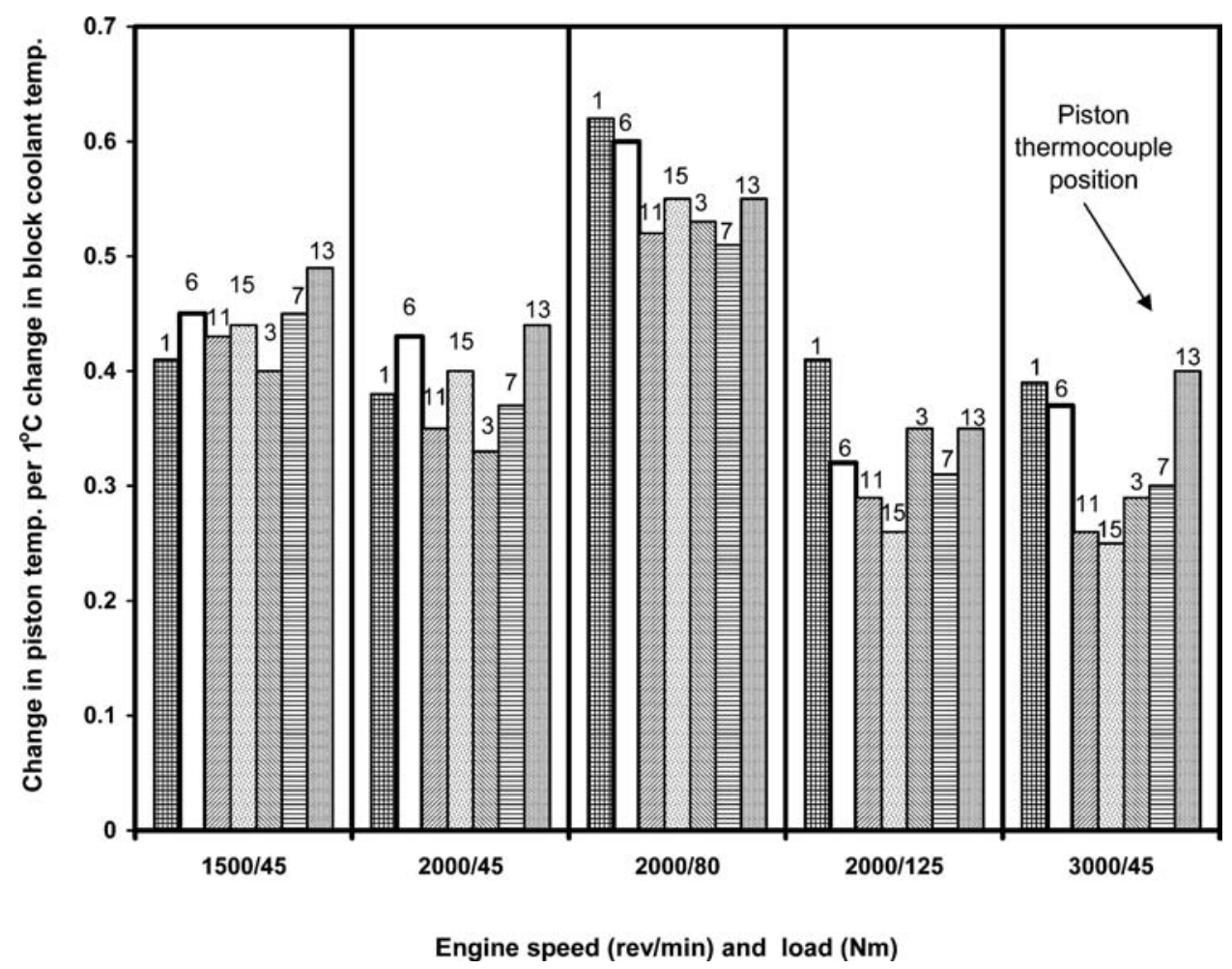

Fig. 7 Change in piston temperatures per degree change in engine block coolant temperature. Injection timing $1^{\circ} \mathrm{CA}$ BTDC for all running conditions, engine head temperature constant at $90{ }^{\circ} \mathrm{C}$

to $227^{\circ} \mathrm{C}$ ) reduced the $\mathrm{HC}$ emission, on average, by about 27 per cent (from 141 down to 103 ppmvC $_{3}$ ). It is worth mentioning that Fig. 9 also shows that injection timing affected HC emission. For example, when the injection timing was advanced by $1^{\circ} \mathrm{CA}$ the $\mathrm{HC}$ emission was reduced by around $4 \mathrm{ppmvC}_{3}$ when the piston temperature was $199^{\circ} \mathrm{C}$. The results presented in Fig. 9 are in general agreement with those of another team of investigators $[\mathbf{9}, \mathbf{2 5}, \mathbf{2 6}]$. These investigators conducted transient load and speed tests in a direct injection high-speed diesel engine, during which they monitored both the exhaust pollutant emissions and the piston surface temperatures. A sudden increase in engine load caused a sharp increase in exhaust HC emissions, which they attributed to the increase in fuelling. However, when the piston temperature was raised by $40{ }^{\circ} \mathrm{C}$ (by increasing the engine coolant temperature), this sharp rise in $\mathrm{HC}$ emission was substantially smaller [25]. Under engine steady running conditions, a $40{ }^{\circ} \mathrm{C}$ rise in piston temperature reduced the HC emission by at least 29 per cent $[\mathbf{2 5}, \mathbf{2 6}]$.

\subsubsection{Oxides of nitrogen}

Figure 10 shows the effect of piston temperature on $\mathrm{NO}_{x}$ exhaust emission. The figure shows that a rise in piston temperature of $38{ }^{\circ} \mathrm{C}$ (from 189 to $227^{\circ} \mathrm{C}$ ) had no significant effect on exhaust $\mathrm{NO}_{x}$ emission. In contrast, the figure shows clearly that the injection timing had a major influence on $\mathrm{NO}_{x}$ emission. For example, for every $1^{\circ} \mathrm{CA}$ that the timing was advanced, the $\mathrm{NO}_{x}$ emission rose by about 30 and 33 ppmv. The results of the team referred to above $[\mathbf{2 5}, \mathbf{2 6}]$ were somewhat less clear-cut than those presented here. Under idling conditions, following engine starting, they did not observe any significant effect on $\mathrm{NO}_{x}$ emission when the piston temperature was raised by $40^{\circ} \mathrm{C}$ (through a rise in coolant temperature). However, the $40{ }^{\circ} \mathrm{C}$ rise in piston temperature increased the $\mathrm{NO}_{x}$ emission significantly when the engine was running at steady state at higher engine loads.

\subsubsection{Smoke emission}

Figure 11 shows the effect of piston temperature on smoke emission. It can be seen from this figure that increasing the piston temperature caused the smoke emission to rise significantly. For example, with the injection timing set at $-1^{\circ} \mathrm{CA}$, raising the piston temperature by $38^{\circ} \mathrm{C}$ (from 189 to $227^{\circ} \mathrm{C}$ ) increased smoke emission, on average, by about 25 per cent (up from 0.61 to 0.76 Bosch smoke units). Figure 11 


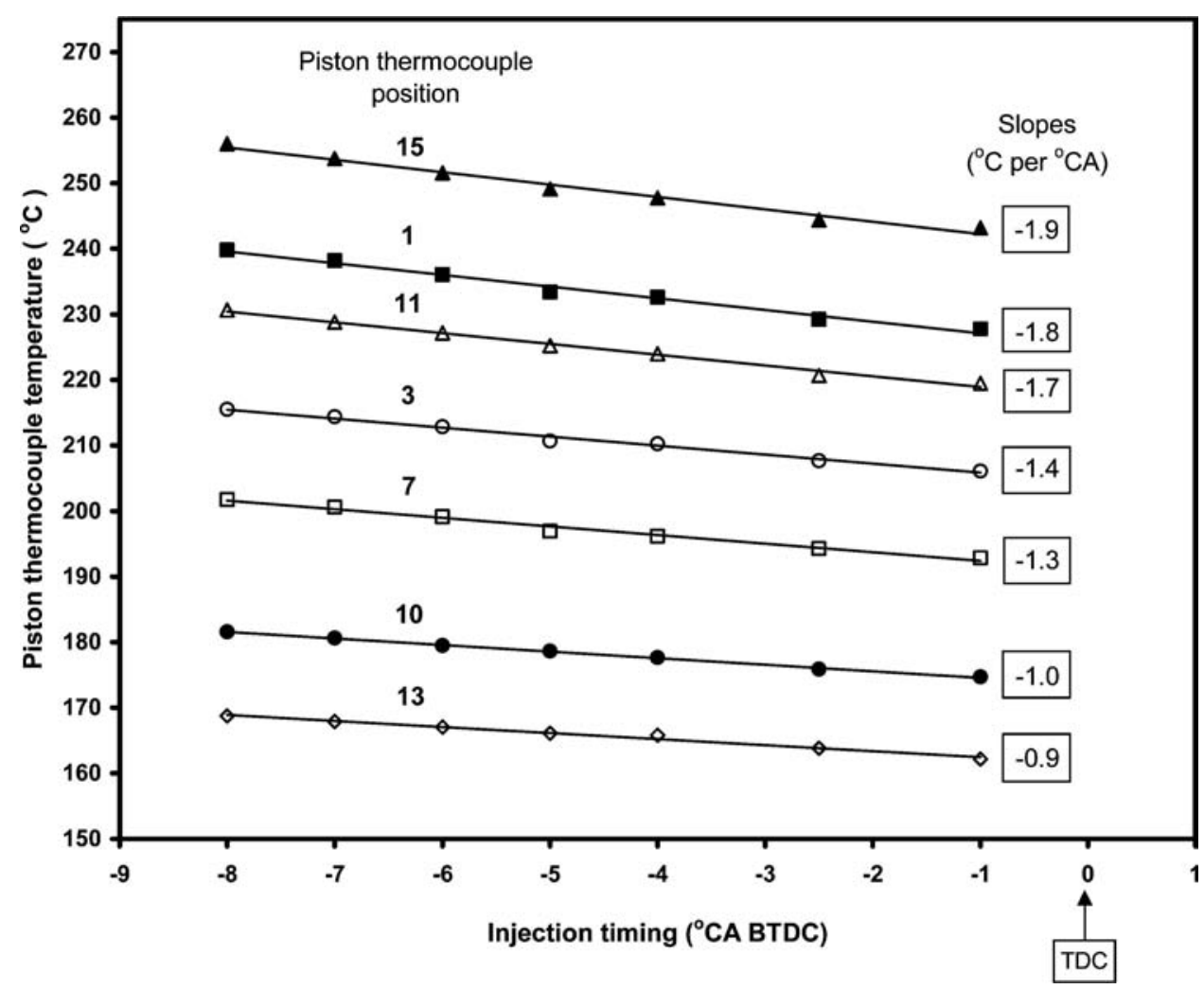

Fig. 8 The effect of injection timing on piston temperature. Engine speed $2000 \mathrm{r} / \mathrm{min}$ and load $80 \mathrm{~N} \mathrm{~m}$, engine head temperature constant at $90^{\circ} \mathrm{C}$, engine block temperature constant at $95^{\circ} \mathrm{C}$

shows that the injection timing also affected smoke emission. For example, advancing the timing by $1^{\circ} \mathrm{CA}$ caused a reduction in smoke emission of about 0.01 to 0.02 Bosch units. The results of Reksowardojo et al. [25] also show a significant rise in smoke emission when the piston temperature was raised. At one engine steady running condition, a rise in piston temperature of $40^{\circ} \mathrm{C}$ (due to higher coolant temperature) caused the exhaust smoke emission to double.

The increase in smoke emission with piston temperature (Fig. 11) is noteworthy and calls for further scrutiny. It is perhaps counterintuitive, despite the agreement of the results with those of Reksowardojo et al. [25]. Intuitively, it might be expected that a rise in piston temperature could improve mixture formation close to the piston surface and, thereby, improve smoke emission. In particular, it is necessary to examine whether the rise in smoke emission might have been caused by a reduction in the engine volumetric efficiency, brought about by the increasing coolant temperature. Figure 12 shows the effect of block coolant temperature on engine fuel and air flowrates and on the air-fuel ratio (at $2000 \mathrm{r} / \mathrm{min}$ and $80 \mathrm{~N} \mathrm{~m}$ ). The increase in coolant temperature from 45 to $105^{\circ} \mathrm{C}$ did indeed reduce the air mass flowrate to the engine by about 6 per cent. However, this was matched by a 6 per cent reduction in the fuel flowrate, due to a reduction in engine friction. As a result, the engine air-fuel ratio remained constant at 31.6. This eliminates the possibility that the increase in smoke emission seen in Fig. 11 was due to a drop in volumetric efficiency and a reduction in the air-fuel ratio. This leaves the interaction of the fuel sprays with the hotter piston bowl as the likely cause for the rise in smoke emission. This matter will be considered in greater detail in the following section.

\subsection{Effects of the piston temperature on fuel spray/wall interaction}

Detailed observations of the spray/wall interactions have been, almost entirely, carried out in stationary rigs, because of severe difficulties in gaining instrumentation access in running engines $[\mathbf{1 - 3}, \mathbf{6}]$.

\subsubsection{Wall-jet flows}

Schunemann et al. [1] injected a diesel spray normally on to a heated surface which was placed 

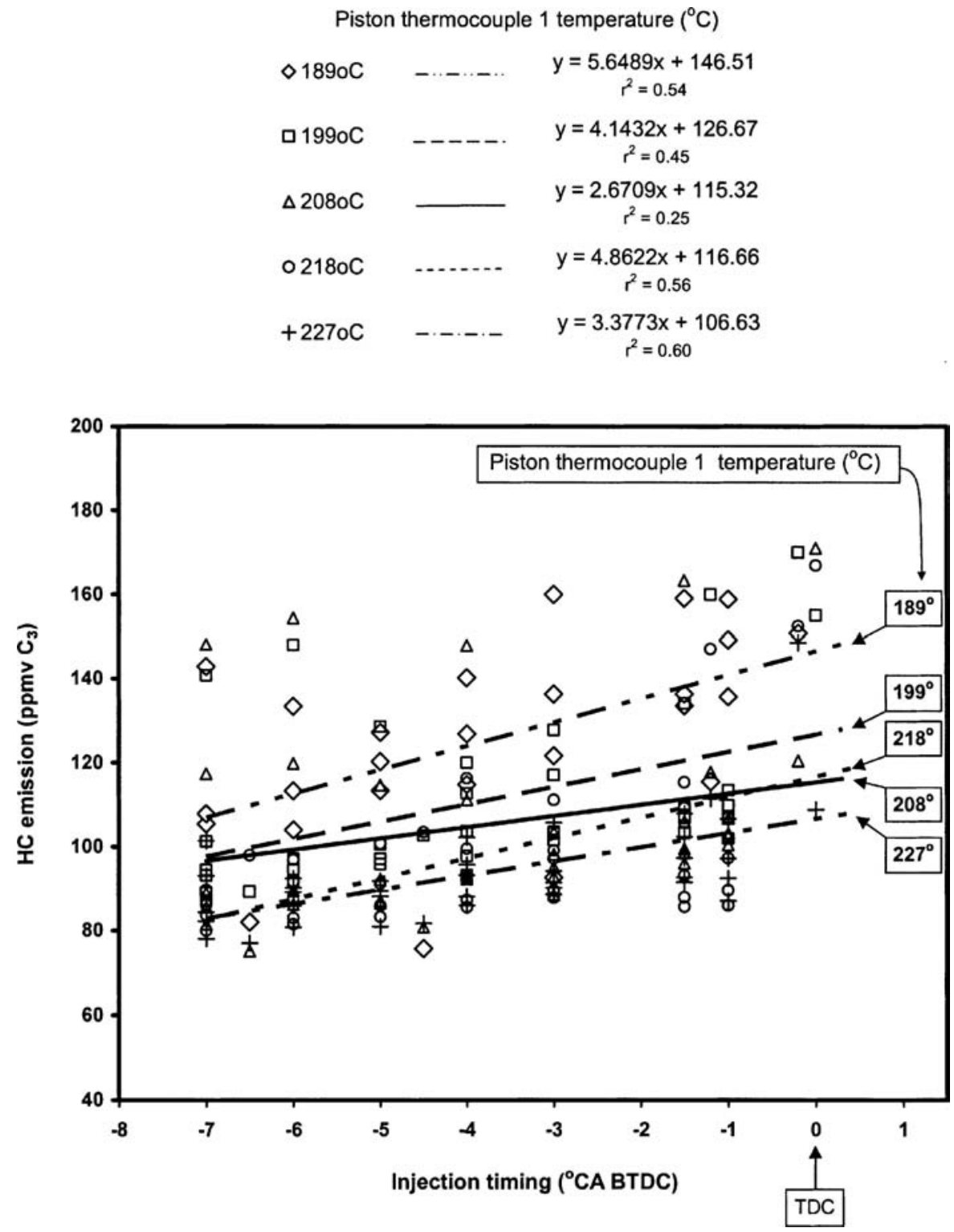

Fig. 9 The effect of piston temperature on HC emissions. Engine speed $2000 \mathrm{r} / \mathrm{min}$ and load $80 \mathrm{~N} \mathrm{~m}$, engine head temperature constant at $90^{\circ} \mathrm{C}$, engine block temperature $45-105{ }^{\circ} \mathrm{C}$

within a stationary chamber containing a quiescent gas at 45 bar and $380^{\circ} \mathrm{C}$. A rise in the heated surface temperature from 120 to $350^{\circ} \mathrm{C}$ caused a reduction of about 25 per cent in the mean size of the spray droplets at $2 \mathrm{~mm}$ above the surface, as well as a slight loss in the peripheral speed of the vortex at the head of the wall-jet. Similar tests by Guerrassi and Champoussin [2] in a high-temperature highpressure rig also showed reductions of around 40 per cent in the mean droplet diameter at $3 \mathrm{~mm}$ above the surface when the wall temperature was raised from 20 to $200^{\circ} \mathrm{C}$. A further surface temperature rise to $400{ }^{\circ} \mathrm{C}$ resulted in a substantial increase in the head vortex peripheral speed (up to 100 per cent greater than that at $20^{\circ} \mathrm{C}$ ). Tests along the same lines by Arcoumanis and Chang [6] (but at atmospheric pressure and temperature) also show a reduction in mean droplet size close to the wall when the surface temperature was raised from 20 to $150{ }^{\circ} \mathrm{C}$. In addition, the turbulence intensity close to the heated surface and the peripheral vortex velocity both increased somewhat.

\subsubsection{Spray droplet impingement}

Fuel droplets impinging on to a hot surface usually show three main patterns of behaviour: (a) they spread on to the surface without rebound or disintegration, to form a thin film; (b) they rebound off the surface; (c) they disintegrate and cause 


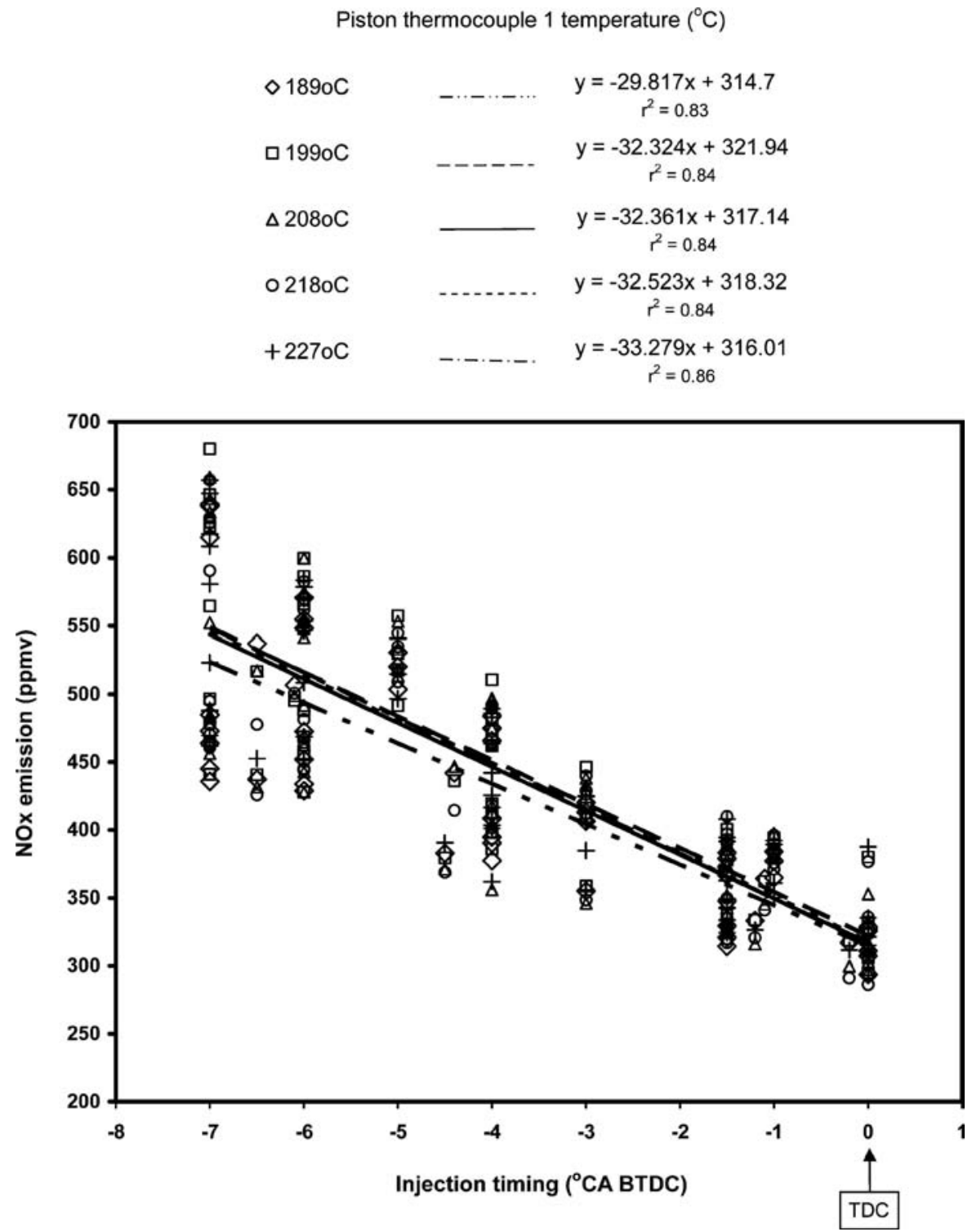

Fig. 10 The effect of piston temperature on $\mathrm{NO}_{x}$ emissions. Engine speed $2000 \mathrm{r} / \mathrm{min}$ and load $80 \mathrm{~N} \mathrm{~m}$, engine head temperature constant at $90^{\circ} \mathrm{C}$, engine block temperature $45-105^{\circ} \mathrm{C}$

the ejection of secondary droplets as well as the deposition of a proportion of their liquid mass on to the wall $[\mathbf{5}, \mathbf{2 7}]$. Which one of these three phenomena will prevail depends mainly on the surface temperature and the droplet thermodynamic properties. During the engine tests described in this paper, the most likely phenomenon prevailing was (a), for the reasons outlined in the following paragraph.

Phenomenon (a) occurs when the droplet boiling point is higher than the temperature of the surface on to which they impinge $[5,27]$. Take $n$-decane, again, to represent the most volatile components of diesel fuel. Section 3.1 showed that $n$-decane would be far from boiling under the engine conditions encountered during the test programme considered in this paper (cylinder gas pressure $>40$ bar and piston surface temperature $<275^{\circ} \mathrm{C}$ ). It follows that the most likely phenomenon experienced by the impinging diesel fuel spray in the test engine was (a). Therefore, the impinging spray droplets would have been deposited on to the bowl surface as a thin film, without breaking up. Direct evidence to support this conclusion comes from seminal work by Naber and Farrell [5]. These investigators injected $n$-decane droplets into helium compressed to 24 bar (i.e. above the critical pressure 21 bar for $n$-decane), where they impinged on to a hot surface at $199^{\circ} \mathrm{C}$ (i.e. below the critical temperature of $346^{\circ} \mathrm{C}$ for $n$-decane). The 


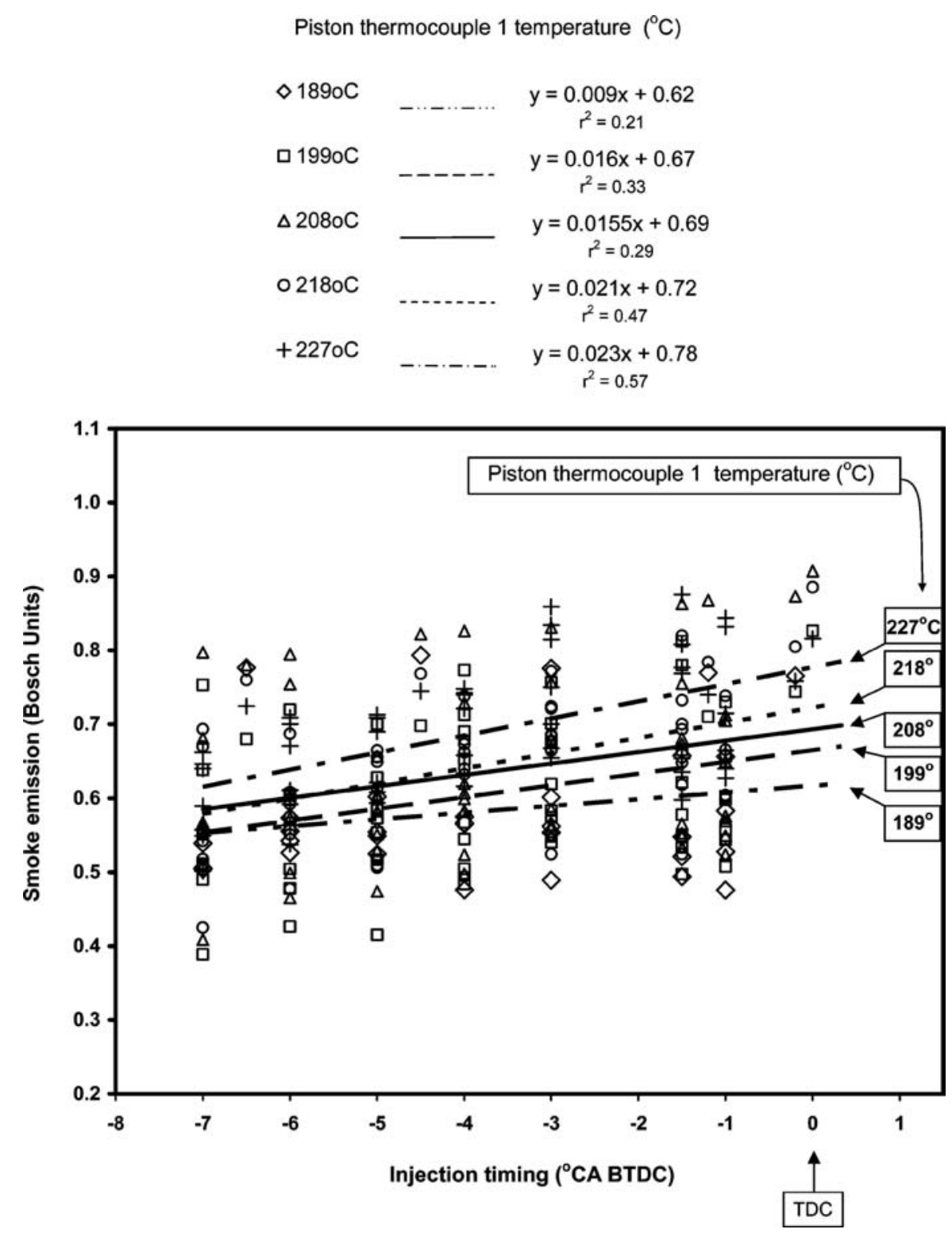

Fig. 11 The effect of piston temperature on smoke emission. Engine speed $2000 \mathrm{r} / \mathrm{min}$ and load $80 \mathrm{~N} \mathrm{~m}$, engine head temperature constant at $90^{\circ} \mathrm{C}$, engine block temperature $45-105^{\circ} \mathrm{C}$

droplets did indeed spread themselves on to the surface without breaking up, forming a thin liquid film. This thin film was not disrupted by the impinging droplets. It was not until Naber and Farrell raised the surface temperature to $323^{\circ} \mathrm{C}$ (i.e. close to the critical temperature for $n$-decane) that the impinging droplets disrupted the liquid film on the hot surface, causing secondary atomization. Naber and Farrell's test conditions are also shown in Fig. 5. It can be seen that these conditions are directly analogous to the engine test conditions: the helium pressure of 24 bar was above the critical pressure for $n$-decane, as was the engine cylinder gas pressure of
40 bar; the heated surface temperature of $199^{\circ} \mathrm{C}$ was well below the critical pressure for $n$-decane, as was the maximum piston bowl temperature of $275^{\circ} \mathrm{C}$.

\subsubsection{Conclusions from the discussion on fuel spray/wall interaction}

The discussions in sections 5.3.1 and 5.3.2 allow a number of tentative conclusions to be reached, within the context of the project presented in this paper. These are:

1. When the piston bowl temperature was progressively raised to a maximum of $275^{\circ} \mathrm{C}$, the 


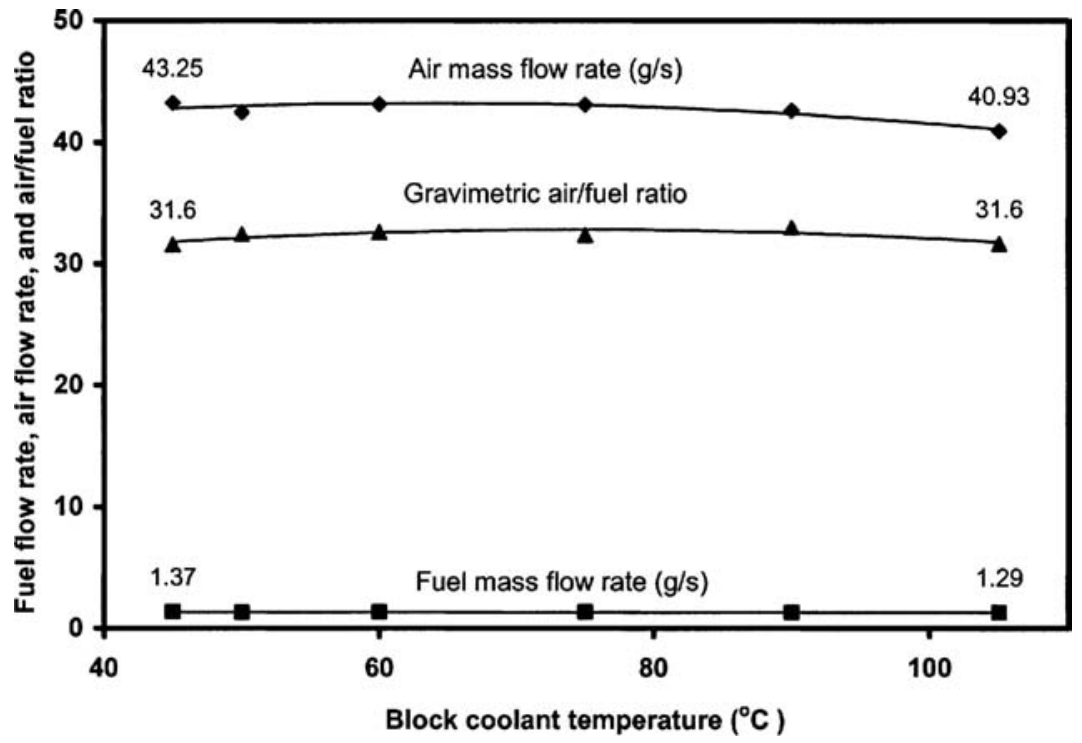

Fig. 12 Effect of block coolant temperature on the fuel flowrate, air flowrate, and air-fuel ratio. Engine speed $2000 \mathrm{r} / \mathrm{min}$ and load $80 \mathrm{~N} \mathrm{~m}$, injection timing $1^{\circ} \mathrm{CA}$ BTDC, engine head temperature constant at $90^{\circ} \mathrm{C}$

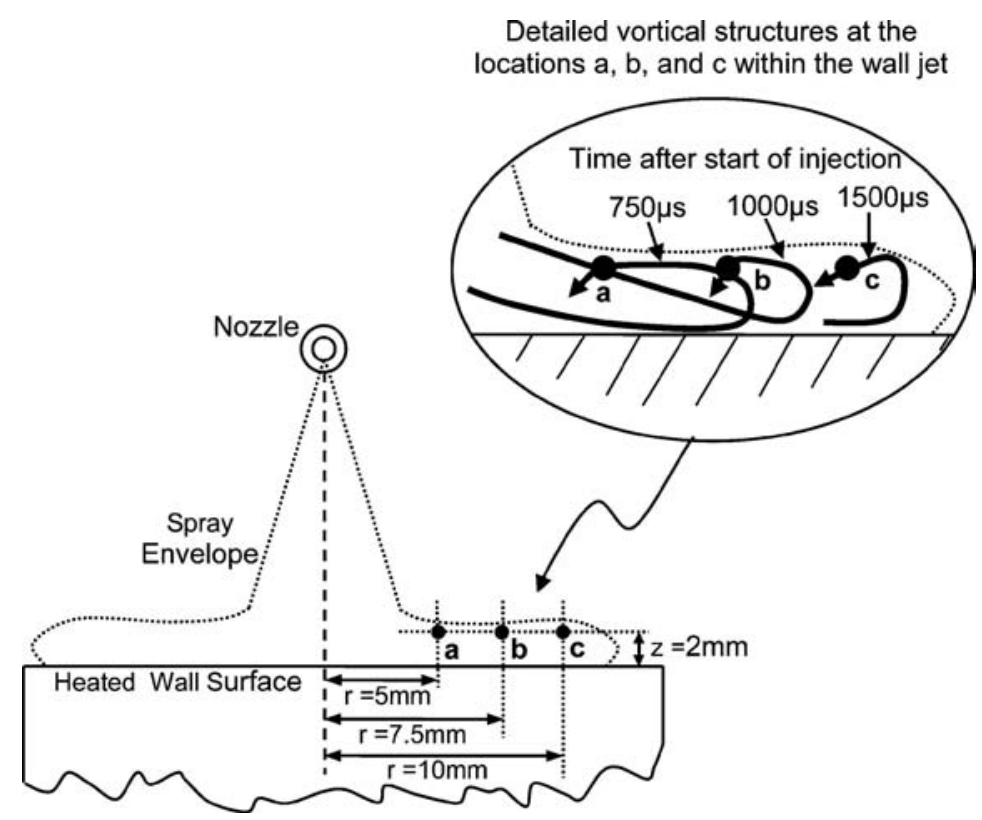

Fig. 13 Evolving vortical structures at three locations (a, b, and c) in a spray impinging on a hot surface (adapted from reference [1]) with quiescent gas at 45 bar and $380^{\circ} \mathrm{C}$, injection pressure $\leqslant 1200$ bar, wall temperature $\leqslant 350{ }^{\circ} \mathrm{C}$

mixture preparation close to the spray impingement points would have been enhanced, firstly, through increasing amount of vapour becoming available and, secondly, through improved air entrainment and air/fuel mixing.

2. At the piston temperatures measured during the test programme (maximum $275^{\circ} \mathrm{C}$ ), it is expected that fuel spray droplets impinging on to the piston would have been deposited as a thin film. Vaporization is expected to have occurred only from the film surface without bulk boiling.

These conclusions help to explain the reduction in HC emission with increasing piston temperature, shown in Fig. 9. However, they do not help to explain, in an obvious manner, the rise in smoke emission 
with increasing piston temperature, observed in Fig. 12. One possible hypothesis could be the following. The improved vapour availability close to the piston surface, coupled with a higher piston surface temperature, increased the rate of fuel pyrolysis and production of soot precursors close to the piston surface. A lack of oxygen in this fuel-rich region could have resulted in a greater number of soot precursors surviving oxidation and forming into soot particles.

\section{CONCLUSIONS}

1. During the engine test programme the instrumented piston worked reliably, except for two thermocouples that failed calibration checks prior to the piston being installed in the engine.

2. The maximum piston temperature recorded close to the piston surface was $275^{\circ} \mathrm{C}$, reached at a near-full-load engine condition $(125 \mathrm{~N} \mathrm{~m}$ and $2000 \mathrm{r} / \mathrm{min}$ ), with engine block and head coolant temperatures of 125 and $90{ }^{\circ} \mathrm{C}$ respectively.

3. Fuel deposited on to the piston bowl during the fuel injection period is expected to have spread on to the piston as a thin film and not experience bulk boiling. It follows that the deposited fuel could not have experienced the Leidenforst phenomenon.

4. Depending on piston location and the engine running condition, the piston temperature rose between 0.3 and $0.6^{\circ} \mathrm{C}$ per $1{ }^{\circ} \mathrm{C}$ rise in block coolant temperature between 60 and $125^{\circ} \mathrm{C}$ (head coolant temperature constant at $90^{\circ} \mathrm{C}$ and injection timing $1^{\circ}$ CA BTDC).

5. The piston temperature at the spray impingement points rose by $1.8^{\circ} \mathrm{C}$ for each $1^{\circ} \mathrm{CA}$ of injection timing advance (engine running at $2000 \mathrm{r} / \mathrm{min}$, $80 \mathrm{~N} \mathrm{~m}$, block and head coolant temperatures constant at 90 and $95^{\circ} \mathrm{C}$ respectively).

6. A rise in piston temperature had a substantial effect in reducing the exhaust $\mathrm{HC}$ emissions. With injection timing set at $1^{\circ} \mathrm{CA}$ BTDC, raising the piston temperature by $38^{\circ} \mathrm{C}$ (from 189 to $227^{\circ} \mathrm{C}$ ) reduced the $\mathrm{HC}$ emission by about 27 per cent (from 141 down to $103 \mathrm{ppmvC}_{3}$ ).

7. The injection timing also had an effect on $\mathrm{HC}$ emission. Advancing the injection timing by $1^{\circ} \mathrm{CA}$ reduced the $\mathrm{HC}$ emission by about $3 \mathrm{ppmvC}_{3}$ when the block coolant temperature was $105^{\circ} \mathrm{C}$ and by about 6 ppmvC $_{3}$ when the block coolant temperature was $60^{\circ} \mathrm{C}$.

8. A rise in piston temperature of $38^{\circ} \mathrm{C}$ (from 189 to $227^{\circ} \mathrm{C}$ ) did not have a significant effect on exhaust $\mathrm{NO}_{x}$ emission.
9. The injection timing had a substantial effect on $\mathrm{NO}_{x}$ emission. Advancing the injection timing by $1^{\circ} \mathrm{CA}$ increased the $\mathrm{NO}_{x}$ emission by about 33 ppmv when the block coolant temperature was $105^{\circ} \mathrm{C}$ and by about $30 \mathrm{ppmvC}_{3}$ when the block coolant temperature was $60^{\circ} \mathrm{C}$.

10. A rise in piston temperature had a substantial effect in raising exhaust smoke emission. With injection timing set at $1^{\circ} \mathrm{CA}$ BTDC, raising the piston temperature by $38^{\circ} \mathrm{C}$ (from 189 to $227^{\circ} \mathrm{C}$ ) raised smoke emission by about 25 per cent (up from 0.61 to 0.76 Bosch smoke units).

11. The injection timing also affected smoke emission. Advancing the injection timing by $1^{\circ} \mathrm{CA}$ caused a reduction in smoke emission of about 0.02 Bosch units when the block coolant temperature was $105^{\circ} \mathrm{C}$ and about 0.01 Bosch units when the block coolant temperature was $60{ }^{\circ} \mathrm{C}$.

12. Measurements of the air-fuel ratio supplied to the engine show clearly that the increase in smoke emission with increasing piston temperature cannot be ascribed to reductions in the air-fuel ratio.

13. When the piston bowl temperature was progressively raised, the mixture preparation close to the spray impingement points is expected to have been enhanced, partly through increasing the amount of vapour and partly through improved air entrainment and air/fuel mixing.

14. Improved air/fuel mixing and fuel evaporation (conclusion 13) close to the piston surface can help explain the observed reduction in $\mathrm{HC}$ emission with rising piston temperature.

15. The observed increase in smoke emission with rising piston temperature is difficult to explain. One possible hypothesis is the following. Greater vapour availability close to the piston surface, coupled with a higher piston surface temperature, increased the rate of fuel pyrolysis and production of soot precursors close to the piston surface. A lack of oxygen in this fuel-rich region could have resulted in a greater number of soot precursors surviving oxidation and forming into soot particles.

\section{ACKNOWLEDGEMENTS}

The assistance of Dr Roy Horrocks of Ford Motor Company, Mr Ed Hartley of former AE Goetze, and Dr Mark Ellis are gratefully acknowledged. 


\section{REFERENCES}

1 Schunemann, E., Fedrow, S., and Leipertz, A. Droplet size and velocity measurements for the characterization of a DI-diesel spray impinging on a flat plate. SAE paper 982545, 1998.

2 Guerrassi, N. and Champoussin, J. C. Experimental study and modelling of diesel spray/wall impingement. SAE paper 960864, 1996.

3 Fujimoto, H., Kusano, S., and Senda, J. Distribution of vapour concentration in a diesel spray impinging on a flat wall by means of exciplex fluorescence method - in case of high injection pressure. SAE paper 972916, 1997.

4 Senda, J., Kobayashi, M., Iwashita, S., and Fujimoto, H. Modeling of diesel spray impingement on a flat wall. SAE paper 941894, 1994.

5 Naber, J. and Farrell, P. Hydrodynamics of droplet impingement on a heated surface. SAE paper 930919, 1993.

6 Arcoumanis, C. and Chang, J.-C. Flow and heat transfer characteristics of impinging transient diesel sprays. SAE paper 940678, 1994.

7 Rao, K. K., Winterbone, D. E., and Clough, E. Combustion and emission studies in a high speed DI diesel engine. IMechE International Conference, paper C448/070, 1992, pp. 117-129.

8 Rao, K. K., Winterbone, D. E., and Clough, E. Laser illuminated photographic studies of the spray and combustion phenomena in a small high speed DI diesel engine. SAE paper 922203, 1992.

9 Miyamoto, N., Ogawa, H., Iemura, A., and Reksowardojo, I. K. Cycle-to-cycle transient characteristics of exhaust gas emissions from diesel engine with different increasing and decreasing load patterns. SAE paper 970750, 1997.

10 Jeon, Y. J., Kim, S. I., Park, S. I., Kim, J. S., Choi, K. H., and Jin, J. H. Thermal load in a heavy duty diesel engine with EUI system. SAE paper 2002-01-0492, 2002.

11 Assanis, D. N. and Syrimis, M. Piston heat transfer measurements under varying knock intensity in a spark ignition engine. SAE paper 971667, 1997.

12 Assanis, D. N. and Friedmann, F. A telemetry linkage system for piston temperature measurements in a diesel engine. SAE paper 910299, 1991.

13 Takamatsu, H. and Kanazawa, T. Piston temperature measurement method for high-speed gasoline engines. Soc. Autom. Engrs Japan, JSAE Rev., 1999, 20(2), 259-279.

14 Russ, S., Kaiser, E. W., and Siegl, W. O. Effect of cylinder head and engine block temperature on HC emissions from a single cylinder spark ignition engine. SAE paper 952536, 1995.

15 Upris, M. C., Jason, R. R., and Anderson, C. L. A comparison of time-averaged piston temperatures and surface heat flux between a direct-fuel injected and carburetted two-stroke engine. SAE paper 980763, 1998.

16 Wiczynski, P. D., Varo, R. G., Archuleta, S. A., and Galarno, M. J. New piston telemetry applied to spherical joint piston development. SAE paper 960056, 1996.

17 Burrahm, R. W., Davis, J. K., Perry, W. D., and Santos, A. D.-L. Development of a piston temperature telemetry system. SAE paper 920232, 1992.

18 Kato, N., Moritsugu, M., Shimura, T., and Matsui, J. Piston temperature measuring technology using electromagnetic induction. SAE paper 2001-01-2027, 2001.

19 Zhao, H., Collings, N., and Ma, T. Warm-up characteristics of surface temperatures in an I.C. engine measured by thermal imaging technique. SAE paper 920187, 1992.

20 Armfield, J. S., Graves, R. L., Beshears, D. L., Cates, M. R., Smith, T. V., and Allison, S. W. Phosphor thermometry for internal combustion engines. SAE paper 971642, 1997.

21 Ogawa, H., Kimura, S., Koike, M., and Enomoto, Y. A study of heat rejection and combustion characteristics of a low-temperature and pre-mixed combustion concept based on measurement of instantaneous heat flux in a direct-injection diesel engine. SAE paper 2000-01-2792, 2000.

22 Vargaftik, N. B. Tables of the Thermophysical Properties of Liquids and Gases, 1975 (John Wiley, New York).

23 Jones, J. B. and Dugan, R. E. Engineering Thermodynamics, 1996 (Prentice-Hall International, London).

24 Fardad, D. and Ladommatos, N. Evaporation of hydrocarbon compounds, including gasoline and diesel fuel, on heated metal surfaces. Proc. Instn Mech. Engrs, Part D, J. Automobile Engineering, 1999, 205(D6), 625-645.

25 Reksowardojo, I. K., Ogawa, H., Miyamoto, N., Enomoto, Y., and Kitamura, T. Time-resolved nature of exhaust gas emissions and piston wall temperature under transient operation in a small diesel engine. SAE paper 960031, 1996.

26 Ogawa, H., Raihan, K. A., IIizuka, K.-I., and Miyamoto, N. Cycle-to-cycle transient characteristics of diesel emissions during starting. SAE paper 1999-01-3495, 1999.

27 Arcoumanis, C., Gavaises, M., and French, B. Effect of fuel injection processes on the structure of diesel sprays. SAE paper 970799, 1997.

\section{APPENDIX 1}

\section{Notation}

BDC bottom dead centre

BTDC before piston top dead centre

CA degrees crank angle

HC gaseous unburned hydrocarbons (wet basis)

IR infrared

$\mathrm{NO}_{x} \quad$ oxides of nitrogen (wet basis) 


\begin{tabular}{|c|c|}
\hline ppmv & $\begin{array}{l}\text { parts per million on a molar } \\
\text { (volumetric) basis }\end{array}$ \\
\hline $\mathrm{ppmvC}_{3}$ & $\begin{array}{l}\text { parts per million (molar) of three- } \\
\text { carbon bonds }\end{array}$ \\
\hline$q$ & total energy transfer to sinks \\
\hline$q_{1}, q_{2}, q_{3}$ & $\begin{array}{l}\text { energy transfer to energy sinks } \\
1,2 \text {, and } 3 \text { respectively }\end{array}$ \\
\hline$r^{2}$ & correlation coefficient \\
\hline$R_{1}, R_{2}, R_{3}$ & $\begin{array}{l}\text { thermal resistance for energy transfer } \\
\text { to energy sinks } 1,2 \text {, and } 3 \\
\text { respectively }\end{array}$ \\
\hline$t_{\mathrm{c}}$ & engine cycle period \\
\hline$t_{\mathrm{o}}$ & engine valve overlap period \\
\hline$T$ & piston surface temperature \\
\hline$T_{1}, T_{2}, T_{3}$ & $\begin{array}{l}\text { temperature of energy sinks } 1,2 \text {, and } \\
3 \text { respectively }\end{array}$ \\
\hline TDC & piston top dead centre \\
\hline
\end{tabular}

\section{APPENDIX 2}

\section{Relationship between the piston temperature and the block coolant temperature}

Taking the energy transfers through an engine piston to be quasi-steady, assume that energy is transferred from a location on the piston surface at temperature $T$ to just three energy sinks. Let the first sink, with temperature $T_{1}$, be the engine block coolant; the second sink, with temperature $T_{2}$, be the engine oil; and the third sink, with temperature $T_{3}$, be the ingested air during the engine valve overlap period. Let the energy loss rate to each sink be $q_{1}, q_{2}$, and $q_{3}$ respectively, along energy transfer paths having thermal resistances $R_{1}, R_{2}$, and $R_{3}$ respectively. Let also the engine valve overlap period be $t_{\mathrm{o}}$ and the total engine cycle period be $t_{\mathrm{c}}$.

The quasi-steady energy loss rate from the piston surface is given by

$$
\begin{aligned}
q= & q_{1}+q_{2}+q_{3}=\frac{1}{R_{1}}\left(T-T_{1}\right)+\frac{1}{R_{2}}\left(T-T_{2}\right) \\
& +\frac{1}{R_{3}}\left(T-T_{3}\right)\left(\frac{t_{\mathrm{o}}}{t_{\mathrm{c}}}\right)
\end{aligned}
$$

The following further assumptions are made: (a) $q$ is constant for a given engine running condition (an accurate assumption for small changes in coolant temperature $T_{1}$ ); (b) the three thermal resistances $R_{1}$, $R_{2}$, and $R_{3}$ are independent of coolant temperature $T_{1}$ (an accurate assumption for small changes in $T_{1}$ ).

Differentiating both sides of equation (1) with respect to $T_{1}$, and taking $q, R_{1}, R_{2}$, and $R_{3}$ to be constant with respect to $T_{1}$, results in

$$
\frac{\partial T}{\partial T_{1}}=\frac{\frac{1}{R_{1}}+\frac{1}{R_{2}}\left(\frac{\partial T_{2}}{\partial T_{1}}\right)+\frac{1}{R_{3}}\left(\frac{\partial T_{3}}{\partial T_{1}}\right)\left(\frac{t_{\mathrm{o}}}{t_{\mathrm{c}}}\right)}{\frac{1}{R_{1}}+\frac{1}{R_{2}}+\frac{1}{R_{3}}}
$$

The value of $\partial T_{2} / \partial T_{1}$ was measured at $2000 \mathrm{r} / \mathrm{min}$ and $80 \mathrm{~N} \mathrm{~m}$ by plotting the oil temperature in the engine sump against the block coolant temperature and determining the slope of the resulting straight line as 0.33 . The third term in the numerator of equation (2) can also be neglected, as the ratio $t_{\mathrm{o}} / t_{\mathrm{c}}$ was very small in the engine tested $(\sim 0.05)$. Therefore, with $\partial T_{2} / \partial T_{1}=0.33$, equation (2) becomes

$$
\frac{\partial T}{\partial T_{1}}=\frac{\frac{1}{R_{1}}+0.33 \frac{1}{R_{2}}}{\frac{1}{R_{1}}+\frac{1}{R_{2}}+\frac{1}{R_{3}}}=\frac{1+0.33 \frac{R_{1}}{R_{2}}}{1+\frac{R_{1}}{R_{2}}+\frac{R_{1}}{R_{3}}}
$$

The energy loss from the piston surface usually has a more direct thermal path to the engine coolant than it does to the engine oil. It also has a direct path to the ingested air flowing past the piston top surface during the engine valve overlap period; however, the quasi-steady thermal resistance is, effectively, quite high due to the short proportion of the engine cycle occupied by the valve overlap period. It is therefore expected that the thermal resistance $R_{1}$ to the block coolant would be lower than $R_{2}$ to the engine oil, and significantly lower than $R_{3}$ to the ingested air. For example:

1. If $R_{1} / R_{2}=\frac{2}{3}$ and $R_{1} / R_{3}=\frac{1}{3}$, then equation (3) gives $\partial T / \partial T_{1}=0.61$.

2. Alternatively, if $R_{1} / R_{2}=\frac{1}{2}$ and $R_{1} / R_{3}=\frac{1}{4}$, then equation (3) gives $\partial T / \partial T_{1}=0.66$.

This range of estimated values for $\partial T / \partial T_{1}$ of $0.61-0.66$ is not too far off the measured range of $0.5-0.6$ at $2000 \mathrm{r} / \mathrm{min}$ and $80 \mathrm{~N}$ m (see Fig. 7). Furthermore, the estimated range for $\partial T / \partial T_{1}$ of $0.61-0.66$ is close to the range of $0.53-0.70$ calculated by the authors from experimental data published in various sources, as follows:

(a) $\partial T / \partial T_{1}=0.53$ for a 2.5 litre, six-cylinder, direct injection gasoline engine (temperature measured at piston cavity edge, $6000 \mathrm{r} / \mathrm{min}$, full load) [18];

(b) $\partial T / \partial T_{1}=0.66$ for a 0.64 litre, single-cylinder, direct injection diesel engine (temperature measured on piston bowl walls, speed about $1200 \mathrm{r} / \mathrm{min}$ load 2 to 6.5 bar brake mean effective pressure) [25]; 
(c) $\partial T / \partial T_{1}=0.70$ for a 12.9 litre, six-cylinder, direct injection diesel engine (temperature measured on piston crown near bowl edge, speed and load not given) [10]; (d) $\partial T / \partial T_{1}=0.65$ for a 0.68 litre, single-cylinder, gasoline engine (temperature measured on piston crown, $1500 \mathrm{r} / \mathrm{min}, 3.5$ bar indicated mean effective pressure) [14]. 